\title{
Attitudes Towards Inheritance Taxation - Results From a Survey Experiment
}

Christiane Gross ${ }^{1}$ (for correspondence and/or offprints)

Institute of Sociology, University of Hanover, Am Klagesmarkt 14-17, 30159 Hannover, Germany e-mail: c.gross@ish.uni-hannover.de

Kerstin Lorek ${ }^{2}$

School of Business and Economics, University of Erlangen-Nuremberg, Findelgasse 7/9, 90402 Nuremberg, Germany

e-mail: kerstin.lorek@,fau.de

Friedemann Richter ${ }^{9}$

School of Business and Economics, University of Erlangen-Nuremberg, Findelgasse 7/9, 90402 Nuremberg, Germany

e-mail: richter.friedemann $@$ gmail.com 
Abstract: Inheritance taxation divides public opinion and is among the most unpopular taxes in many countries, although only a minority of people have to pay it. Using a survey experiment with vignettes on a sample of German citizens $(\mathrm{N}=479)$, we examine attitudes towards inheritance taxation. Our results reveal several relevant dimensions for a proposed fair inheritance tax rate (PITR): The PITR decreases with a close relationship between testator and heir and when the asset is a family-occupied house or family enterprise compared with a "lump sum". It increases with the value of bequest and income of the heir representing equity considerations. Respondents advocate higher tax rates to reduce fiscal budget deficits. Respondents with a strong family orientation propose a low inheritance tax rate.

JEL Codes: H2 J62

Keywords: economic inequality, estate tax, factorial survey, fair taxation, inheritance tax, intergenerational mobility, preferences for redistribution, social mobility, survey experiments, tax attitudes, vignette 


\section{Introduction}

Transfer taxes on bequests and gifts are one possible instrument to mitigate wealth concentration through a redistribution of wealth and income (redistribution function). ${ }^{1}$ However, although only a minority of people have to pay inheritance taxes, the inheritance taxation divides public opinion and is among the most unpopular taxes in many countries.

Our study analyses via an experimental design which factors are considered relevant by laypeople for inheritance tax rates and which respondent characteristics explain a general tendency to favor high or low inheritance tax rates. Our contribution to the literature is twofold. First, our results contradict previous findings and show that inheritance taxation as such is accepted by a large majority of the respondents of our survey. We deviate from former surveys by allowing for a continuous response (i.e., the selection of a specific tax rate) instead of a binary (dis)approval of the tax. We believe this approach to be more appropriate since the respondents are forced to reflect on the question more deeply. ${ }^{2}$ Second, we argue that attitudes towards inheritance taxation are based on different preferences for redistribution. Theoretical and empirical research has identified selfinterest, social justice and fairness considerations, social values, and social mobility as main influences for differences in preferences for redistribution (e.g., Alesina and Angeletos, 2005; Alesina and La Ferrara, 2005; Durante and Putterman, 2007). In order to explain different attitudes towards inheritance taxation, we consider the first three factors to be the most important.

Survey experiments using vignettes (i.e., factorial survey experiments) combine the advantages both of surveys and those of experiments. Internal validity can be increased by the integration of experiments and by "avoiding the shortcoming of unidimensional stimuli" (Auspurg and Hinz, 2015, p. 10), while external validity (which is usually low within experiments) can be increased by using random or at least more heterogeneous samples (as opposed to using only students, as is done in

\footnotetext{
${ }^{1}$ In standard textbooks, two additional functions are ascribed to taxes: financing the public budget (fiscal function) and correcting externalities (i.e., Pigouvian tax) (Kaplow, 2007). This paper is focused on the redistribution function.

${ }^{2}$ It can be argued that this approach might force the respondents to choose a non-zero answer and therefore overestimates the support for inheritance taxation. However, choosing a tax rate of zero was an obvious option, and we still observe variance within the respondent, which allows for interpreting the causal mechanisms and implies that there is prevalent support for non-zero tax rates.
} 
most of the laboratory research) (Mutz 2011, Auspurg and Hinz 2015). Factorial survey experiments are widely used in sociology to analyze beliefs and judgements, especially on norms and justice but also for behavioral studies on moving or job decicions (see Wallander, 2009 for a review on the application of factorial surveys).

Applying a survey experiment using vignettes, we are able to disentangle the causal effects of self-interest motives (expecting bequest), fairness considerations (heir's income, value of bequest), and social values, especially family-based values (relationship of heir to bequeather, type of bequest), on the selection of a fair tax rate. Additionally, we include governmental debt as a measure signaling the financial needs of the public budget. The cumulative advantage of having already-high earnings and receiving bequests in addition might be considered unfair. Based on vertical equity arguments, we predict that respondents support a progressive tax schedule that increases with the value of the bequest and emphasizes ability-to-pay principles. The family-based argument concentrates on the character of the inheritance as taxable transfer. Whether intra-family bequests should be regarded as taxable transactions is debatable. This argument is supported by societal values that consider the family to be a unit of care and that supports its members and society as a whole.

Regarding Germany, polls show a slight majority opposing inheritance taxes. According to Schrenker and Wegener (2007), 52\% of respondents would appreciate a repeal of the inheritance tax. This is in line with the results of Lettke (2004), who also finds that $58 \%$ of respondents oppose the inheritance tax. Similar opinions are expressed in other countries. For example, Moon (2009) finds that $67 \%$ of respondents in the US favor the elimination of estate taxes. He finds that the supporters of the elimination are mainly older, are married, and have a yearly income above $\$ 75,000$. Unfortunately, no demographic information of opponents of the tax is available for Germany. These rates of rejection of the tax can be seen as a surprising result considering the fact that only a small fraction of people will be liable to inheritance taxation. Consequently, the total revenue of the German inheritance tax measured as a share of total tax revenue falls short compared with other German taxes, such as income tax or sales tax (Bundesministerium der Finanzen, 2014), and the revenue of the inheritance tax in Germany is quite low in international comparison (OECD, 2014). 
Supporters of estate taxes highlight the redistributive character of a progressive estate tax on "unearned" bequests that effects only a small part of the population and can strengthen equality of opportunity. Opponents of estate taxes mention double-taxation, harmful effects on small and family businesses, and the time at which it is imposed (for a discussion of arguments see, e.g., Gale and Slemrod, 2001; Graetz and Shapiro, 2011; Prabhakar, 2008; Prabhakar et al., 2008). Whether people's preferences and attitudes towards taxes are mainly driven by narratives or other underlying factors, such as self-interest or fairness motives, remains an open question.

Prabhakar (2008) argues that opponents of estate taxes provide stories and frames, which have been more persuasive than the collection of numbers and statistics provided by supporters of the tax. However, substantial opposition to estate taxes remains, even if appropriate frames are used (Prabhakar, 2008). It remains unclear whether these attitudes indicate a fundamental rejection of inheritance taxation as a matter of principle or only a rejection of specific tax legislation. These questions are only rarely addressed in research.

Negative (context) effects of inequality have been shown for various dimensions of daily life, such as poor health, low human well-being, high crime rates, low social trust and cohesion, and high anxiety and stress levels (Wilkinson and Pickett, 2010). One key factor for the reproduction of social inequality is intergenerational transfers. Intergenerational transfers and the wealth distribution are clearly linked. Numerous studies show a positive intergenerational correlation of income and wealth and high values for the intergenerational elasticity of wealth (e.g., Solon, 1992, for the US; Clark and Cummins, 2015, for England). Consistent cross-country evidence is provided by Black and Devereux (2011) and Corak (2013). In addition to economic capital, further family background characteristics, such as education, health, and social behavior are also positively correlated across generations (see, e.g., Black and Devereux, 2011, for an overview).

As mentioned by Black and Devereux (2011), intergenerational correlations are not questionable per se, and the "optimal" level of intergenerational mobility is unknown and depends on the underlying causes and determinants. Intergenerational immobility becomes problematic only if the principle of meritocratic societies (in which individual achievement should influence a person's social status) is violated. Although the research on the underlying channels of wealth transmission has only just begun and is not yet conclusive, there is some evidence that wealth begets wealth, 
independent of the inheritance of skills (see, e.g., Black et al. 2015). Moreover, as Corak (2013, p. 79) concludes, "an emerging body of evidence suggests that more inequality of incomes in the present is likely to make family background play a stronger role in determining the adult outcomes of young people, with their own hard work playing a commensurately weaker role."

We take these observations as a starting point in discussing attitudes towards inheritance taxation. Inheritance taxes can be considered a useful part of the overall tax system and policy tools if the redistribution of wealth is a desired goal. In addition to revenue needs, the reduction of economic immobility is, in fact, one of the most important justifications for inheritance taxation. In the same vein, legal literature in favor of inheritance taxes proposes equality of opportunity or resource equality as a guiding principle. This means that each member of society should begin life with similar resources and life chances (Alstott, 2007). However, both the chances of receiving a bequest and the value of the inheritance increase with the previous wealth and income of the heir, which leads to an accumulation of capital in these families, as is shown for Germany (Szydlik, 2004) and further European countries (Albertini and Radl, 2012).

In Section 2, key elements of the German inheritance tax and a comparison of international inheritance and estate tax regulations are given. Section 3 provides both the major arguments from which we derive our hypotheses as well as the dimensions that matter in explaining the attitudes towards a fair inheritance tax rate. In Section 4, the survey experiment, the dataset, and the methods for analyzing it are introduced and described. The last two sections provide and discuss the results (5) and concluding remarks (6).

\section{Background knowledge about inheritance taxation - Germany in international comparison}

This section first provides a brief institutional overview of inheritance tax design in Germany. Second, differences and similarities of inheritance taxation in selected industrialized countries are pointed out. There are two different concepts of intergenerational transfer taxation (see Cremer and Pestieau, 2006; Gale and Slemrod, 2001): Estate taxes are levied on the total bequest of the testator, whereas inheritance taxes are levied on the share received by the recipients. Most OECD countries, including Germany, impose inheritance taxes. In most countries, transfers causa mortis and transfers 
inter vivos are treated almost identically and laid down in the same tax code to reduce tax avoidance activities.

$<$ Table 1 here $>>$

Inheritance tax design allows for the application of different tax rates and allowances linked to certain characteristics of the beneficiaries. A strong preference to relieve close family members can be observed in all countries (see Table 1). For the case of Germany, the degree of kinship is taken into account, and allowances and tax rates differ according to three tax classes. Moreover, children of the deceased person are granted an additional pension allowance, which depends on and decreases with age (ErbStG, §17).

In Germany, tax rates vary depending on the volume of bequest from between $7 \%$ and $30 \%$ in Tax Class I (e.g., father, grandfather), between $15 \%$ and $43 \%$ in Tax Class II (e.g., uncle), and between $30 \%$ and $50 \%$ in Tax Class III (e.g., non-relatives). A progressive tax schedule is implemented in most countries. In the US, the current estate tax is effectively a flat tax for estates subject to it. In Switzerland, most bequests are untaxed because spouses and decedents are taxexempt in almost all cantons.

Substantial tax allowances for transfers of companies are granted. Some conditions, such as the continuation of business and thresholds for the increase in the sum of salaries, are required in the tax code. However, the regulations entail the tradeoff between the protection of businesses to continue their economic activity (prevent potential job losses) and fairness considerations (equal burden of similar assets). Although decisions of the German Federal Constitutional Court in 2006 and the Federal Fiscal Court in 2009 support the privileged taxation of certain assets if this is in the public interest, such privileges must be well justified and should not be implemented through tax valuation procedures (Houben and Maiterth, 2009). Thus, the German inheritance tax law remains in flux. Houben and Maiterth (2009) provide a more detailed overview on the inheritance tax exemptions of German businesses. Further exemptions apply to owner-occupied property. A variety of additional 
exemptions, allowances, and valuation rules exists; however, the study at hand is focused on the above-mentioned dimensions.

Inheritance taxes are usually more tailored towards certain groups of beneficiaries, i.e., those providing different tax classes depending on kinship. However, similar exemptions and exclusions are also applied in estate tax systems. The US, for example, allows extra deductions for transfers to surviving spouses or for the transfer of family businesses (see Gale and Slemrod, 2001; US Tax Code). Although the tax base and subject are determined differently, it is clear that similar dimensions are incorporated in international inheritance and estate tax design.

\section{The inheritance tax rate and preferences for redistribution}

Four main approaches have been found to explain different support for redistribution: self-interest, social justice and fairness, social values and norms, and social mobility. A comprehensive overview of preferences for redistribution is given by Alesina and Giuliano (2011). They highlight the own position on the income ladder among other personal characteristics as well as fairness considerations as being important factors in shaping attitudes towards redistribution. Jaime-Castillo and SáezLozano (2014) highlight self-interest and political ideology as the driving forces in explaining preferences for redistribution.

We concentrate on self-interest, fairness considerations, and family values as we consider them to be appropriate and most important in the context of redistribution through inheritance taxation. We add the size of the public budget deficit as a further channel that might explain differing attitudes towards taxation. In the following sections, the guiding hypotheses ${ }^{3}$ are derived.

\footnotetext{
3 The hypotheses are named according to the data level they refer to: $\mathrm{R}$ (espondent) hypotheses are based on respondent characteristics and $\mathrm{V}$ (ignette) hypotheses consider situational characteristics of the vignette, not the respondents.
} 


\subsection{The role of self-interest}

Self-interest is one of the main explanations for different preferences for redistribution (e.g., Rutström and Williams, 2000). The distinction of individuals in beneficiaries or taxpayers in the case of inheritance taxation depends on the individuals' prospect of receiving an inheritance. Respondents should propose high tax rates if they do not expect to receive taxable bequests or gifts, and vice versa. A rational actor should support a high tax rate if he or she was not concerned by it in the past (and will not be in the future) because this actor could benefit from governmental redistribution without own monetary contributions:

$\mathrm{R} 1$ : The proposed fair inheritance tax rate is higher if the respondent is not expecting a bequest.

\subsection{Fairness Considerations}

The importance of fairness considerations can be seen in a study by Alesina, Cozzi, and Mantovan (2012). The authors study a political economy model to explain the evolution of differing preferences for redistribution at the country level and show that the perception of inequalities as either fair or unfair can lead to different steady states in tax policy. The same level of inequality might be considered fair if its underlying wealth has been accumulated through effort, whereas it might be considered unfair if it has been acquired solely by luck, illegal activities (such as corruption), or birth, as is the case with inheritances. ${ }^{4}$ Based on this differentiation of the source of income or wealth, a preference for redistributing inheritances through taxation can be expected, as is shown by Krawczyk (2010) in an experimental investigation. However, not only the inequalities themselves, but also the redistributional mechanism (through tax policy) to resolve them needs to be justified based on fairness principles in order to gain acceptance.

In tax design, vertical and horizontal equity principles are considered to incorporate general notions of fairness based on differences in ability to pay (see Kaplow, 2007). A properly designed

\footnotetext{
${ }^{4}$ An often-mentioned argument disagrees with the notion of inheritances as based on birth and luck: Inheritances could be achieved through effort if one assumes the heir is recompensated for working in a family business or for providing care for the bequeather. However, different perceptions of (un)deserved inheritances should alter only the intercept but not the marginal effects of income and inheritance value.
} 
inheritance tax could be a potentially useful instrument to redistribute and foster an equality of opportunities. Focusing on equity considerations, people with different initial income situations could be taxed differently because the income of the heir can be considered an indicator for his or her inherent ability rather than merely for economic capital (see, i.e., Mankiw et al., 2009). People with higher inherent abilities are able to pay more taxes than people with lower inherent abilities. In addition, a high-income earner is regarded as less needy than a low-income earner. We therefore hypothesize:

V1: The proposed inheritance tax rate increases with the heir's income.

We hypothesize that the fairness principles also need to be reflected in the inheritance tax schedule to gain acceptance by taxpayers. Applying the vertical equity principle, people who receive a bequest of higher value would have to hand over a larger part of their bequest to the state. Although the desired level of progressivity remains an empirical question and is answered in the empirical part of this text, we expect that:

V2: The proposed inheritance tax rate increases with the value of bequest.

\subsection{Family values}

Most bequests and inter-vivos transfers take place between family members, so it is important to take a closer look at values and norms that consider the family as well as the family-state relation when explaining differences in redistribution preferences. In Germany in 2013, about $63 \%$ of all taxable transfers (tax cases) - gifts and bequests - were transferred within the family. This number would have been even higher if transfers to non-private organizations and charities had been able to be excluded from the remaining $37 \%$. Moreover, $82 \%$ of the total value of these tax cases is transferred among family members (Statistisches Bundesamt, 2014). The notion of bequests and inter-vivos gifts within the family as taxable transfers, however, is controversial. If the family is seen as a unit and a collective actor and not the individual family member itself, the bequest would not be considered a transfer and should therefore not be taxed. 
Bengtson (2001) provides arguments for the "increasing importance of multigenerational (three or more) relationships for well-being and support over the course of their lives." A generational contract exists that obligates family members not only legally but also socially to support other members, especially in times of need (Albertini et al., 2007). "The family is [...] one of the key institution for transmitting assets, knowledge, and values across generations [...]” (Alstott, 2009, p. 124). Furthermore, families are seen as and often act as collectives (Bourdieu, 1996). Resources may be pooled within families, and the property of individual family members may not be considered individual property, but rather "family property" (Beckert, 2008). Families are already treated differently in tax law (e.g., through joint income taxation for spouses or exemptions for children), emphasizing the importance and identity ascribed to family and the interpretation of family as a collective unit. Furthermore, even if family ideals do not exclude inheritance taxation per se (Alstott, 2009), conservative as well as functional ideals of families would require a special treatment of families by leaving wealth within the family. Both ideals lead to the belief in the family as a main institution for support within its members and in family property as a resource for this support. Inheritance taxation interferes with these resources, and bequests within the family institution should be protected in the form of low tax rates or exemptions. In consideration of the family principle, the relationship between testator and heir should impact the perception of a fair tax rate.

V3: The proposed inheritance tax rate increases with decreasing closeness in the relationship between testator and heir.

This idea holds true even more if the asset represents family wealth, as is the case for owneroccupied property or the family enterprise. In addition to the monetary value, both assets can have psychological or emotional value for the bequeather and the heir. The family home can hold memories of the deceased person and the heir's childhood, as can the family enterprise. People ascribe different meanings to bequeathed objects that can hardly be standardized and converted to money (Stum, 2000). A family home or family enterprise could be inherited by a group of heirs, e.g., siblings. In this case, a division of the inherited asset is often not possible or only possible at high costs. Family enterprises are burdened with the maintenance of their business and the protection of 
jobs while meeting their tax obligations. Therefore, the asset itself should affect the perceived fair tax rate.

V4: The proposed inheritance tax rate is higher if the type of bequest is a "lump sum" compared with owner-occupied property or a family enterprise.

In addition, there are personal characteristics at the respondent level that can have an effect on proposed tax rates. Independent of the inheritance case per se, people who support family-oriented values might consider inheritance taxation to be illegitimate state interference. The family is valued as the higher authority compared with the state, and intra-familiar support is preferred over the government in situations where redistribution decisions are made.

R2: The proposed inheritance tax rate increases with decreasing family-orientation of the respondent.

\subsection{Governmental debt and inheritance taxation}

In addition to the already-defined factors influencing redistribution preferences, we take governmental debt into account. The relationship between public spending and revenue raising comprises one of the fundamental concerns in public finance literature. Musgrave (1969, p.797) summarizes the issue as follows: "A theory of public finance remains unsatisfactory unless it comprises both the revenue and expenditure sides of the fiscal process.” However, in practice, both topics are often discussed independently. Therefore, we include a simple expenditure side-measure while focusing on the acceptance of the inheritance tax. Respondents can adjust their proposed tax rate depending on the level of governmental debt. We consider it necessary to include the expenditure side because any survey in which people can decide on their tax rate will presumably be biased towards the lower bound. Including a measure for public spending raises awareness that taxes are used to finance public goods. As experimental evidence by Alm, McClelland, and Schulze (1992) shows, people do not pay taxes merely to comply with tax laws, but rather, they value the public goods that can be financed through taxation. We include governmental debt because it entails the whole budget and is therefore less vulnerable to different preferences in budget composition. 
High public debt signals a stronger need for tax revenue, as is the case in situations with welloff finances. The higher need might justify higher tax rates and could alter the willingness to pay higher taxes in order to improve the fiscal situation. We therefore hypothesize:

V5: The proposed inheritance tax rate is higher if governmental debt is high.

However, taxpayers could also perceive high debt as a signal for weak governmental performance, which would presumably decrease their willingness to pay high taxes. In the context of tax compliance, it has been shown that public spending inefficiencies weaken tax morale (Barone and Mocetti, 2011). Thus, a higher governmental debt could, ceteris paribus, also decrease the proposed inheritance tax rate. Whether the inefficiency explanation or the revenue-need explanation dominates is tested in the empirical part.

\section{Data and Methods}

\subsection{Study design}

Respondents were sampled from an online access opt-in-panel, the WiSo-Panel, with approximately 10,000 participants (Effective October 2011) that was run at the University of Freiburg in Germany (Göritz, 2014). In online access opt-in panels, interested people can sign up for participation in online surveys. As long as they choose to participate in the panel, they receive invitations to answer surveys. The WiSo-Panel is used only for scientific purposes and non-commercial research. Panelists were 40 years old on average, and $62 \%$ were female. Most of them lived in Germany (95\%). The panelists' educational backgrounds were slightly more advanced than the German average. In September 2012, a random sample selection of these panelists $(\mathrm{n}=2,022)$ were invited via email to participate in an online survey that included a survey experiment with vignettes (see Section 4.2.). The invitation stated the general topic as well as the expected response time of the survey. Respondents participated voluntarily and were remunerated for completing surveys. 479 people answered the survey, yielding a response rate of $23.7 \%$.

Although our sample is more heterogeneous than in most laboratory experiments, the collected respondent data is not representative of the German population and effects concerning respondents' 
characteristics need to be interpreted with care. Tests of external validity, e.g. by using other samples, are necessary to draw generalised conclusions. However, we are mainly interested in the causal effects of different treatments on respondents' decisions. For this case, Auspurg and Hinz (2015: 62) postulate that "the validity of (FS) experiments does not necessarily rely on the use of general population samples. In cases in which one wishes to test causal mechanisms, this goal can be achieved with convenience samples [...] Problems of generalizability to other respondent samples arise, however, if these mechanisms are moderated by the respondents' characteristics (i.e., if there are interactions between respondent variables and vignette variables)." We have tested several theory-driven interaction effects between respondent and vignette variables and have not detected one significant (cross-level) interaction effect, which can be seen as an indicator for not having a problem with the generalisability of the vignette effects. However, we cannot completely invalidate the issue.

The respondent sample is described in Table 2. The net household income (in $€$ ) has been logarithmized to meet the requirement of normal distribution. These sociodemographic variables are controlled for in the models in Table 5, while the following two variables concern the hypotheses on respondent level ( $\mathrm{R} 1$ and $\mathrm{R} 2$ ): $29 \%$ of respondents expect a bequest of more than $€ 25$,000 in the future. The metric index of family orientation, ${ }^{5}$ with 1 indicating a high family orientation and strong intra-familiar support values, has an average value of .69.

\section{$<$ Table 2 here $>>$}

We have three different types of data:

\footnotetext{
${ }^{5}$ 0-1 standardized index generated from the question "How much do you agree with the following statements?" and the four statements "Relatives should support each other like the older generation used to do. You should support those relatives who are worse off than you. You do not have to support those relatives you do not like. The relatives you support should sooner or later give their assistance in return." Although these questions adapted from Gerlitz (2008) are not optimal, we decided to use them instead of developing a new scale (answer categories: completely agree, agree, not agree, completely disagree).
} 
(1) Basic information among the respondents, such as gender or age, which was provided by the access panel and contains no missing data.

(2) Respondent data collected in our online survey, including information about the educational background, household income, and family orientation of the respondent, and whether the respondent him- or herself is expecting a bequest. Missing values within these data are treated by single imputations since only one value is missing among the variables needed for hypothesis testing. The other variables serve as control variables. The slightly underestimated standard errors of the control variables due to single imputation (rather than multiple imputation) are not reported, nor do they affect the coefficients and standard errors of the variables tested within the hypotheses. The imputation model for net household income with the highest share of missing values $(4.8 \%)$ includes gender, age, and educational background.

(3) Vignette judgments per respondent are described in the next section (4.2.) and do not contain any missing data.

\subsection{Survey experiments with vignettes}

Survey experiments using vignettes are an experimental method often used to examine attitudes, beliefs, and judgements (Alves and Rossi, 1978; Jasso and Opp, 1997; Ellmann, 2009). Vignettes are short descriptions of people or situations with varying dimensions (treatments). As each respondent has to give several vignette judgments, the impact of each dimension on the vignette judgment (dependent variable) can be estimated. The main advantages of this method are (a) the experimental design, which allows for a causal interpretation of the effects; (b) a concrete situation, which is more realistic for the respondents than an abstract question; and (c) a social desirability bias that is almost fixed because several dimensions are being judged in common (for a comprehensive overview on survey experiments with vignettes see Auspurg and Hinz, 2015).

We constructed vignettes with varying cases of inheritance (see Figure 1 for an example) to examine which of the given dimensions are seen as relevant for a proposed inheritance tax rate (PITR). The PITR can be regarded as a measure of revealed preferences for redistribution. The varying dimensions are written in bold and include the heir's gender and monthly gross income, the 
value of the heritage, the type of bequest, the relation between testator and heir, and the governmental debt of the country in which they live. We have no hypothesis concerning the impact of gender, but we followed the idea of using both gender categories for the heir (to avoid the impression of being male- or female-dominated) and only one gender for the bequeather (father, grandfather, uncle) to avoid receiving an additional dimension.

\section{$<<$ Figure 1 here $>>$}

We included six dimensions, which are displayed in Table 3. Each dimension has several categories; in our study, we have $2 \times 2 \times 3 \times 5 \times 3 \times 4=720$ vignette options, which are called the vignette universe. After the exclusion of 4 implausible combinations, ${ }^{6} 716$ vignettes remained. A sample of 480 vignettes was drawn randomly and assigned to sets of six. Therefore, each respondent answered six vignettes, and each set was assigned to six respondents. Literature on methodological aspects of vignette use show that six vignettes are reasonable and do not prompt fatigue or overload for the respondents. Sauer et al. (2011) show that even 20 or more vignettes are manageable by respondents without any decrease in answer consistency. Teti et al. (2016) show no effect of age on answer consistency, even for respondents aged 70 and older with 10 vignettes.

Respondents were allowed to browse back and forth between the vignettes and to change their judgements to minimize order effects. We also tested for order effects by including the first vignette by respondents only and received robust results concerning the coefficients while the standard errors strongly increased due to a loss of $5 / 6$ of the cases. With 479 respondents and six vignettes each, we obtained 2,874 vignettes. Table 4 shows the distribution of the vignette characteristics. The distribution is not completely rectangular due to the exclusion of implausible combinations. However, there are no significant correlations between dimensions, which suggests a successful randomization.

\footnotetext{
${ }_{6}^{6}$ These were friend and family enterprise, family enterprise with value of $€ 25,000$ and $€ 100,000$, and owneroccupied property with value of $€ 25,000$.
} 


\section{$<<$ Table 3 here $>>$ \\ $<<$ Table 4 here $>>$}

The dependent variable (proposed inheritance tax rate in percent, PITR) was displayed on a scale from $0 \%$ to $100 \%$, with 5 -percent steps resulting in 21 possible values. This variable is interpreted as being metric and has an empirical range in our study from 0 to $100 .{ }^{7}$ The average PITR was $16.4 \%$ with a standard deviation of 17.0 . Only $6 \%$ of the respondents proposed an inheritance tax rate of $0 \%$ across all six vignettes. These cases are included in the hierarchical linear models to avoid biased level-two effects. Although the dependent variable is far from being normally distributed (see Figure 2), we decided not to use the logarithmized value for the analysis since the basic results do not differ between the two versions (standard value in \% versus logarithmized value) and the standard value allows for a straightforward interpretation of the coefficients. The values of the vignette dimensions are not completely randomly distributed since we excluded some unrealistic combinations (see Fn 6). Therefore, the distribution is not rectangular in some dimensions. Additionally, not all invited participants finished the questionnaire, and some vignettes were thereby not answered.

\section{$<<$ Figure 2 here $>>$}

\subsection{Data Analysis}

Data gathered via survey experiments using vignettes is hierarchically nested since several vignette judgments (in our case, six) were given by the same respondent. To account for this data structure, we applied multi-level analysis using HLM version 6 software (Raudenbush et al., 2004). Auspurg and Hinz (2015, p. 91) strongly recommend using random-intercept models with fixed slopes on data collected via factorial survey experiments if researchers' main interest is the detection of vignette effects rather than the detection of respondent effects and random-intercept models are an adequate

\footnotetext{
${ }^{7}$ The metric scale may cause respondents to vary their vignette judgements, whereas they would tend to say no to the tax within a binary scale. This could be examined in future research.
} 
and parsimonious solution in doing so. It is critical to note that both random-intercept and randomslope models are both also known as random effect models (compared with fixed-effects models). As the coefficients of models with additional random slopes do not vary significantly from those of random-intercept models (deviance test ${ }^{8}$ ), we decided on the more simple random-intercept model that is presented in the following. With $j=1, \ldots, N$ groups (respondents) and $i=1, \ldots, N$ (vignettes), the Level 1 model is:

$$
\begin{aligned}
& (\text { PITR })_{i j}= \\
& \left.\beta_{0 j}+\beta_{1 j} \text { (heir_inc }\right)+\beta_{2 j}(\text { bequest_value })+\beta_{3 j}(\text { relation })+ \\
& \left.\beta_{4 j} \text { (bequest_type }\right)+\beta_{5 j}(\text { gov_debt })+\beta_{6 j}(\text { heir_gender })+R_{i j} .
\end{aligned}
$$

The Level 2 model is

$$
\begin{aligned}
& \left.\beta_{0 j}=\gamma_{00}+\gamma_{01} \text { (expect_bequest) }+\gamma_{02} \text { (family_oriented }\right)+\gamma_{03}^{T}(X)+U_{0 j} \text { and } \\
& \beta_{1 j}=\gamma_{10}, \beta_{2 j}=\gamma_{20}, \beta_{3 j}=\gamma_{30}, \beta_{4 j}=\gamma_{40}, \beta_{5 j}=\gamma_{50}, \beta_{6 j}=\gamma_{60},
\end{aligned}
$$

with $\mathrm{X}$ as a vector of additional control variables at the respondent level (e.g., gender, age).

Following the linear mixed model can be defined as

$$
\begin{aligned}
& (\text { PITR })_{i j}=\gamma_{00}+\gamma_{10}\left(\text { heir_inc }_{\mathrm{ij}}+\gamma_{20} \text { (bequest_value }\right)_{\mathrm{ij}}+\gamma_{30}(\text { relation })_{\mathrm{ij}}+\gamma_{40}{\text { (bequest_type })_{\mathrm{ij}}+} \\
& \gamma_{50}(\text { gov_debt })_{i j}+\gamma_{60}(\text { heir_gender })_{i j}+\gamma_{01}(\text { expect_bequest })_{\mathrm{j}}+\gamma_{02}(\text { family_oriented })_{\mathrm{j}}+\gamma_{03}^{T}(X)_{\mathrm{j}}+ \\
& U_{0 j}+R_{i j} .
\end{aligned}
$$

Missing data on respondent levels were imputed as described in section 4.1 so that all models would contain the same cases.

\footnotetext{
8 The deviance test (implemented in HLM) examines if the more complex model with random intercept and random slopes has a significantly better model fit than the more parsimonious model with random intercepts and fixed slopes. Since the deviance test is not significant, we decided on the parsimonious model. We also used the Hausman test (implemented in Stata), which tests for random versus fixed effects and confirms that it is appropriate to use random intercept models with fixed slopes.
} 


\section{Results}

The results of the random-intercept models that explain the PITR based on vignette characteristics (which describe a certain inheritance case) and respondent characteristics are displayed in Table 5. All independent variables are grand-mean centered; therefore, the intercept shows an average proposed inheritance tax rate of $16 \%$. The unstandardized coefficients can be interpreted straightforwardly as absolute changes of the dependent variable. For example, if the heir's monthly gross income is $€ 3,500$, the PITR is 2.6 percentage points higher on average than for the reference category ( $€ 1,750$ monthly gross income).

$<$ Table 5 here $>>$

The variances in the random-intercept-only model (RIO, not shown in tables) reveal an intraclass correlation (ICC) of $65.0 \%$, meaning that $65 \%$ of the overall variance is between respondents and the remaining $35 \%$ is within respondents at the vignette level.

Model 1 includes the vignette characteristics only. All vignette characteristics explain $22.6 \%$ of the error variance in Level 1 (measured by the reduction of error variance compared with the random-intercept-only model). All hypotheses at the vignette level (V1-V5) are supported significantly: As already mentioned, the PITR is higher when the heir's monthly gross income is higher, an effect that is even stronger for the highest income category of $€ 10,000$, which affects a PITR that is 7.0 percentage points higher (compared with the reference category of a $€ 1,750$ monthly gross income, which supports Hypothesis V1). The higher the value of the bequest, the higher the PITR is (which supports Hypothesis V2): With a $€ 10$ million bequest, a PITR that is 9.4 percentage points higher is proposed compared with a value of bequest at $€ 25$,000. With a closer relationship between testator and heir (uncle/grandfather/father as compared with friend), a 1.7-/2.3-/3.9-percentage-point lower inheritance tax rate is proposed (supporting Hypothesis V3). Additionally, an emotional value of the bequest leads to a PITR that is reduced by 4.1 and 2.1 percentage points regarding family-enterprise and owner-occupied property, respectively (which 
supports Hypothesis V4). If governmental debt is high, the PITR is 1.6 percentage points lower (compared with a case with low governmental debt). The heir's gender variation in the vignette text has no effect on the PITR.

Model 2 additionally includes respondent characteristics that test Hypotheses $\mathrm{R} 1$ and $\mathrm{R} 2$. Respondents who themselves expect a heritage in the future do not propose a lower inheritance tax rate (which contradicts Hypothesis R1). Since previous research shows that expecting a bequest is correlated with a high income, we also tested the hypothesis using only the respondents' income. The results remain robust and contradict the self-interest hypothesis. The higher the respondent's family orientation is, the lower the PITR is (which supports Hypothesis R2). However, only a small share of $2.2 \%$ for the variance between respondents can be explained by respondent characteristics.

We calculate the true tax liability for selected cases to contrast the judgments in the vignettes with real inheritance tax cases (see Table 6). Bequests in Tax Class I (from father and grandfather) are tax free for the lower values $(€ 25,000$ and $€ 100,000)$, display relatively low tax rates for the mid-values ( $€ 500,000$ and $€ 1,000,000$ ), and display effective tax rates of $18.2 \%$ and $22.5 \%$ for the highest value of $€ 10$ million. On average, the PITR rises from $12.6 \%$ for the lowest value to $22.0 \%$ for the highest value (bequest from a father). It seems that respondents do not account for tax exemptions in their judgments. Therefore, proposed rates are higher than effective tax rates for the lower values and become more equal to true tax liabilities for the higher values. Non-related heirs (e.g., bequest from a friend) face lower allowances and higher tax rates. Lump-sum bequests from friends are taxed at effective rates from $6.0 \%$ up to about $50 \%$ for the aforementioned bequest categories. Excluding the lowest value, the PITR are lower than effective tax rates for non-relatives. Considering the type of bequest, enterprises and properties are taxed at lower rates compared with lump-sum transfers because additional exemptions and valuation methods exist. The average PITR in the vignettes is consistently lower for these assets compared with a lump sum. 


\section{Concluding remarks}

Our study is the first to show via an experimental design which of the proposed dimensions are considered relevant by laypeople for inheritance tax rates. Additionally, we analyse which respondent characteristics affect the tendency to favor high or low inheritance tax rates. However, the focus of our work is on the situation in Germany and uses a rather specific sample, so respondent effects should be interpreted with caution. The causal effects of the dimensions on inheritance tax rates, however, may be considered relatively robust due to the experimental design and the effect of the vignette dimensions not being moderated by respondent characteristics.

In our data we find that the perception of a fair inheritance tax rate depends on the heir's income, the value of the bequest, the relationship between testator and heir, as well as the bequeathed asset itself and the governmental debt. A fair tax rate increases with a higher value of the bequest, the income of the heir, and governmental debt. This tax rate decreases with an increasing familial relationship between testator and heir and if the asset is a family-occupied house or family enterprise in contrast to "lump sum". Inheritance tax design should therefore consider need-based, equity-based, and family-based dimensions in order to be perceived as fair.

On the one hand, these results support the redistributional character of the inheritance tax as the heir's financial situation is considered. On the other hand, the study emphasizes the importance of the family as a unit of wealth and property and a redistributing institution by itself. In contrast to other studies, we find general support for the inheritance tax in Germany, as $94 \%$ of all respondents proposed tax rates larger than zero on average. However, tax rates are suggested to be relatively low and highly-educated people who are more likely to support inheritance tax in general are slightly overrepresented within the sample.

Our results suggest that the self-interest argument (respondents expecting a bequest) does not play a role in the proposed inheritance tax rate. This is a surprising result because self-interest motives have received great attention in the theoretical literature.

We consider our results relevant for three issues in the broader context of taxation and inheritance taxation in particular. First, a fair tax can be considered a precondition for high tax 
morale (Kirchler et al., 2008; Torgler et al., 2008; for a comprehensive overview on tax morale and tax compliance, see Torgler, 2002). Thus, knowledge about the dimensions that shape fairness perception helps us to understand and affect taxpayers' compliance decisions. Second, although the monthly gross income of heirs does not play a role in inheritance taxation in Germany or in other countries, we find sizeable effects for income differences of heirs in the proposed inheritance tax rate. This finding is potentially interesting because it prompts a discussion of an integrated taxation of income and inheritances. Third, in our study, governmental debt served as a proxy for the need for tax revenue. Because governmental debt influences the perception of a fair tax rate, it could be argued that not only the need for revenue but also the fiscal usage of a tax is of importance to people and should be communicated transparently.

Although survey experiments using vignettes allow for the analysis of several dimensions at a time, there are several additional dimensions that would be worth considering in future research. Future research may, for example, concentrate on other recipients of inheritances, including charitable donations, or the emotional/reciprocal relationship between the bequeather and bequeathed in addition to the presence of more than one heir. Conducting an international comparison and/or a larger representative sample would be interesting, especially considering different contextual and cultural values and norms that shape fairness perceptions and different concepts of individualism versus family orientation. 


\section{Acknowledgements}

Financial support by the Emerging Field Initiative (EFI) of the University of Erlangen-Nuremberg is gratefully acknowledged. For their comments on former versions of this paper we would like to thank Sebastian Bähr, Gerhard Krug and Benjamin Wirth. For assistance during the research process we thank Julia Linhardt, Alexander Patzina, Marie-Therese Stärk, Sven Uthmann and Anne Warziniak. We are very grateful for the comments by the reviewers and the editor, which helped us to improve the paper considerably.

\section{References}

Albertini, M., Kohli, M., Vogel, C.: Intergenerational transfers of time and money in European families: common patterns — different regimes? J. Eur. Soc. Policy 17(4), 319-334 (2007)

Albertini, M., Radl, J.: Intergenerational transfers and social class: inter-vivos transfers as means of status reproduction? Acta Sociol. 55(2), 107-123 (2012)

Alesina, A., Angeletos, G.-M.: Fairness and redistribution. Am. Econ. Rev. 95(4), 960-980 (2005)

Alesina, A., Cozzi, G., Mantovan, N.: The evolution of ideology, fairness and redistribution. Econ. J. 122(565), 1244-1261 (2012)

Alesina, A., Giuliano, P.: Preferences for redistribution. In: Bisin, A., Benhabib J. (eds.) Handbook of Social Economics, pp. 93-132. North Holland, San Diego Amsterdam (2011)

Alesina, A., La Ferrara, E.: Preferences for redistribution in the land of opportunities. J. Public Econ. 89(5-6), 897-931 (2005)

Alm, J., McClelland, G.H., Schulze, W.D.: Why do people pay taxes? J. Public Econ. 48(1), 21-38 (1992)

Alstott, A. L.: Equal opportunity and inheritance taxation. Harvard Law Rev. 121(2), 469-542 (2007)

Alstott, A. L.: Family values, inheritance law, and inheritance taxation. Tax Law Rev. 63(1), 123-137 (2009)

Alves, W.M., Rossi, P.H.: Who should get what? Fairness judgements or the distribution of earnings. Am. J. Sociol. 84(3), 541-564 (1978)

Auspurg, K., Hinz, T.: Factorial Survey Experiments. Quantitative Applications in the Social Sciences. Sage, Los Angeles London New Dehli Singapore Washington DC Boston (2015)

Barone, G., Mocetti, S.: Tax morale and public spending inefficiency. Int. Tax Public Finan. 18(6), $724-749(2011)$

Beckert, J.: Inherited Wealth. Princeton University Press, Princeton (2008)

Bengtson, V. L.: Beyond the nuclear family: the increasing importance of multigenerational bonds. J. Marriage Fam. 63(1), 1-16 (2001)

Black, S. E., Devereux, P.J.: Recent developments in intergenerational mobility. In: Card D., Ashenfelter O. (eds.) Handbook of Labor Economics, vol.4, pp. 1487-1541. Elsevier , Amsterdam (2011) 
Black, S.E., Devereux, P.J., Lundborg, P., Majlesi, K.: Poor little rich kids? The determinants of the intergenerational transmission of wealth. Knut Wicksell Working Paper 6, School of Economics and Management, Lund (2015).

Bourdieu, P.: On the family as a realized category. Theor. Cult. Soc. 13(3), 19-26 (1996)

Bundesministerium der Finanzen (BMF). Kassenmäßige Steuereinnahmen nach Steuerarten in den Kalenderjahren 2010-2012. http://www.bundesfinanzministerium.de/Content/DE/Standardartikel/Themen/Steuern/Ste uerschaetzungen_und_Steuereinnahmen/2016-05-24-steuereinnahmen-nach-steuerarten-20102015.pdf?_blob=publicationFile\&v=4 cited 18 Apr 2014 (2014).

Clark, G., Cummins, N.: Intergenerational wealth mobility in England, 1858--2012: surnames and social mobility. Econ. J. 125(582), 61-85 (2015)

Corak, M.: Income inequality, equality of opportunity, and intergenerational mobility. J. Econ. Perspect. 27(3), 79-102 (2013)

Cremer, H., Pestieau, P.: Wealth transfer taxation: a survey of the theoretical literature. In: Kolm, S.C., Ythier, J.M. (eds.), Handbook of the Economics of Giving, Altruism and Reciprocity: Applications, pp. 1107-1134. Elsevier, Amsterdam (2006)

Durante, R., Putterman, L., Weele, J.: Preferences for redistribution and perception of fairness: an experimental study. J. Eur. Econ. Assoc. 12(4), 1059-1086 (2007)

Ellman, I.M., Braver, S., MacCoun, R.J.: Intuitive lawmaking: the example of child support. J. Empir. Leg. Stud. 6(1), 69-109 (2009)

European Commission: Cross-country review of taxes on wealth and transfers of wealth. https://ec.europa.eu/taxation_customs/sites/taxation/files/docs/body/2014_eu_wealth_tax_ project_finale_report.pdf (2014)

Gale, W.G., Slemrod, J.B.: Rethinking the estate and gift tax: overview. NBER Working Paper series No. 8205. National Bureau of Economic Research, Cambridge (2001)

Gerlitz, J.-Y.: Distributive Gerechtigkeit in der Familie. Zur Integration sozialer und persönlicher Faktoren bei der Erklärung von Präferenzen von Familienideologien. Berl. J. Soziol. 18(4), 623$648(2008)$

Göritz, A.S.: Determinants of the starting rate and the completion rate in online panel studies. In: Callegaro, M., Baker, R., Bethlehem, J., Göritz, A.S., Krosnick, J.A., Lavrakas, P.J. (eds.), Online Panel Research: A Data Quality Perspective, pp. 154-170. John Wiley \& Sons, Ltd, Chichester, UK (2014)

Graetz, M.J., Shapiro, I.: Death by a Thousand Cuts: The Fight over Taxing Inherited Wealth. Princeton University Press, Princeton (2011)

Houben, H., Maiterth, R.: Inheritance tax-exempt transfer of German businesses: imperative or unjustified subsidy? - An empirical analysis. arqus Discussion Papers in Quantitative Tax Research No. 95. Arbeitskreis Quantitative Steuerlehre, Berlin (2009)

Jaime-Castillo, A.M., Sáez-Lozano, J.L.: Preferences for tax schemes in OECD countries, self-interest and ideology. Int. Pol. Sci. Rev. 37(1), 81-98 (2014)

Jasso, G., Opp, K.-D.: Probing the character of norms: a factorial survey analysis of the norms of political action. Am. Sociol. Rev. 62(6), 947-964 (1997)

Kaplow, L.: Taxation. In: Polinsky, A.M., Shavell, S. (eds.), Handbook of Law and Economics, vol.1, pp. 647-756. Elsevier, Amsterdam, London (2007)

Kirchler, E., Hoelzl, E., Wahl, I.: Enforced versus voluntary tax compliance: the "slippery slope" framework. J. Econ. Psychol. 29(2), 210-225 (2008) 
Krawczyk, M.: A glimpse through the veil of ignorance: equality of opportunity and support for redistribution. J. Public Econ., 94(1-2), 131-141 (2010)

Lettke, F.: Subjektive Bedeutungen des Erbens und Vererbens. Ergebnisse des Konstanzer Erbschafts-Surveys. Z. Soziol. Erzieh. Sozi. 24(3), 277-302 (2004)

Mankiw, N.G., Weinzierl, M., Yagan, D.: Optimal taxation in theory and practice. J. Econ. Perspect. 23(4), 147-174 (2009)

Moon, M.: How do Americans feel about taxes today? Tax Foundation's 2009 survey of U.S. attitudes on taxes, government spending and wealth distribution. Tax Foundation Special Report No 166. Tax Foundation, Washington DC (2009)

Musgrave, R.A.: Cost-benefit analysis and the theory of public finance. J. Econ. Lit. 7(3), 797-806 (1969)

Mutz, D. C.: Population-Based Survey Experiments. Princeton University Press, Princeton (2011)

OECD: Revenue Statistics - OECD Member Countries: Tax revenue as percentage of GDP. http://stats.oecd.org/Index.aspx?QueryId=21699\# cited 18 Apr 2014 (2014)

Prabhakar, R.: Wealth taxes: stories, metaphors and public attitudes. Polit. Quart., 79(2), 172-178 (2008)

Prabhakar, R., Rowlingson, K., White, S.. How to Defend Inheritance Tax. Fabian Society, London (2008)

Raudenbush, S.W., Bryk, A.S, Congdon, R.: HLM 6 for Windows [Computer software]. Scientific Software International Inc., Lincolnwood, IL (2004)

Rutström, E.E., Williams, M.B.: Entitlements and fairness. J. Econ. Behav. Organ. 43(1), 75-89 (2000)

Schrenker, M., Wegener, B.: Was ist gerecht? Ausgewählte Ergebnisse aus dem International Social Justice Project 1991-2007. ISJP-Arbeitsbericht Nr. 150. Humboldt Universität Berlin(2007)

Sauer, C., Auspurg, K., Hinz, T., Liebig, S.: The application of factorial surveys in general population samples: the effects of respondent age and education on response times and response consistency. Surv. Res. Methods 5(3), 89-102 (2011)

Solon, G.: Intergenerational income mobility in the United States. Am. Econ. Rev. 82(3), 393--408 (1992)

Statistisches Bundesamt.: Finanzen und Steuern: Erbschaft- und Schenkungsteuer 2013. Statistisches Bundesamt, Wiesbaden (2014)

Stum, M.S.: Families and inheritance decisions: examining non-titled property transfers. J. Fam. Econ. Issues 21(2), 177-202 (2000)

Szydlik, M.: Inheritance and inequality: theoretical reasoning and empirical evidence. Eur. Sociol. Rev. 20(1), 31-45 (2004)

Teti, A., Gross, C., Knoll, N., Blüher, S.: Feasibility of the factorial survey method in aging research. consistency effects among older respondents. Res. Aging 38(7),715-741 (2016)

Torgler, B.: Speaking to theorists and searching for facts: tax morale and tax compliance in experiments. J. Econ. Surv. 16(5), 657-683 (2002)

Torgler, B., Demir, I.C., Macintyre, A., Schaffner, M.: Causes and consequences of tax morale: an empirical investigation. Econ. Anal. Policy 38(2), 313-339 (2008)

Wallander, L.: 25 years of factorial surveys in sociology: a review. Soc. Sci. Res. 38(3), 505-520 (2009)

Wilkinson, R. Pickett, K.: The Spirit Level: Why Greater Equality Makes Societies Stronger. Bloomsbury, New York (2010). 


\section{Tables and Figures}

Table 1: International comparison of inheritance tax laws

\begin{tabular}{|c|c|c|c|c|}
\hline & Country & Tax rates & Allowances & $\begin{array}{l}\text { Level of tax } \\
\text { administration }\end{array}$ \\
\hline \multirow[t]{2}{*}{ Estate Tax } & Great Britain & $\begin{array}{l}40 \% \\
\text { (36\% if } 10 \% \text { of total } \\
\text { bequest is donated to } \\
\text { charity) }\end{array}$ & $\begin{array}{l}\text { General allowance of } \\
325,000 \text { GBP (nil rate } \\
\text { band); higher allowances } \\
\text { for spouse and civil } \\
\text { partner }\end{array}$ & National \\
\hline & USA & $40 \%$ & $\begin{array}{l}\text { Allowances for spouses } \\
\text { and donations to } \\
\text { charities }\end{array}$ & $\begin{array}{l}\text { National; also } \\
\text { subnational taxes } \\
\text { in parts }\end{array}$ \\
\hline \multirow[t]{11}{*}{$\begin{array}{l}\text { Inheritance } \\
\text { Tax }\end{array}$} & Germany & $\begin{array}{l}\text { Marginal tax rates vary } \\
\text { between } 7 \text { and } 50 \% \\
\text { depending on total value } \\
\text { of bequest and kinship }\end{array}$ & $\begin{array}{l}\text { Spouse, civil partner: } € \\
\text { 500,000; children: } € \\
\text { 400,000; grandchildren: } \\
€ 200,000 \text {; other people } \\
\text { in Tax Class I: } € \\
\text { 100,000; people in Tax } \\
\text { Class II: } € 20,000\end{array}$ & $\begin{array}{l}\text { Revenue } \\
\text { distributed at } \\
\text { subnational level } \\
\text { (federal tax); tax } \\
\text { regulation } \\
\text { administered at } \\
\text { national level }\end{array}$ \\
\hline & Denmark & $\begin{array}{l}15 \% \text { on total value of } \\
\text { bequest above allowance } \\
\text { of } 263,100 \text { DKK; }\end{array}$ & $\begin{array}{l}\text { No tax for spouse or civil } \\
\text { partner }\end{array}$ & National \\
\hline & & $\begin{array}{l}\text { Additional } 25 \% \text { for non- } \\
\text { related heirs. }\end{array}$ & & \\
\hline & & $\begin{array}{l}\text { Above } 1,786,600 \text { DKK: } \\
50 \%\end{array}$ & & \\
\hline & France & $\begin{array}{l}\text { Marginal tax rates vary } \\
\text { between } 5 \text { and } 55 \%\end{array}$ & $\begin{array}{l}\text { No tax for spouse or civil } \\
\text { partner }\end{array}$ & National \\
\hline & & $\begin{array}{l}\text { depending on total value } \\
\text { of bequest and kinship }\end{array}$ & $\begin{array}{l}\text { Allowance for disabled } \\
\text { and unemployable people }\end{array}$ & \\
\hline & $\begin{array}{l}\text { the } \\
\text { Netherlands }\end{array}$ & $\begin{array}{l}\text { Spouse, civil partner, } \\
\text { children }\end{array}$ & $\begin{array}{l}\text { No tax for donations to } \\
\text { state or charities; spouse }\end{array}$ & National \\
\hline & & $\begin{array}{l}10 \% \text { up to } 20 \% \text { for } \\
\text { acquisitions above } € \\
118,254 ; \text { grandchildren }\end{array}$ & $\begin{array}{l}\text { or civil partner: } € \\
616,880 \text {, deducting } 50 \% \\
\text { of joint pensions }\end{array}$ & \\
\hline & & $\begin{array}{l}18 \% \text { up to } 36 \% \text { for } \\
\text { acquisitions above } € \\
118,254 ; \text { others }\end{array}$ & $\begin{array}{l}\text { entitlements; allowance } \\
\text { for ill or disabled } \\
\text { children, different } \\
\text { allowances depending on }\end{array}$ & \\
\hline & & $\begin{array}{l}30 \% \text { up to } 40 \% \text { for } \\
\text { acquisitions above } \\
€ 118,254\end{array}$ & kinship & \\
\hline & Switzerland & $\begin{array}{l}\text { Different regulations } \\
\text { depending on Canton }\end{array}$ & $\begin{array}{l}\text { Different regulations } \\
\text { depending on Canton }\end{array}$ & $\begin{array}{l}\text { Subnational } \\
\text { (Cantons) }\end{array}$ \\
\hline $\begin{array}{l}\text { No Estate } \\
\text { or } \\
\text { Inheritance } \\
\text { Tax }\end{array}$ & \multicolumn{4}{|c|}{ Australia (abolished in 1979), Austria (abolished in 2008), Canada (abolished in 1972) } \\
\hline
\end{tabular}


Table 2: Respondent sample

\begin{tabular}{lrrrrr}
\hline & Cases & Mean & SD & MIN & MAX \\
\hline $\begin{array}{l}\text { Respondent expecting bequest }>€ 25,000(1= \\
\text { yes, O = no) }\end{array}$ & 478 & .29 & .45 & 0 & 1 \\
Family-oriented (index; 1 = high, $0=$ low) & 479 & .69 & .19 & 0 & 1 \\
Gender (1 = male) & 479 & .40 & .49 & 0 & 1 \\
Age (in years) & 479 & 44.66 & 14.57 & 18 & 82 \\
Educational background & & & & & \\
$\quad$ Low (Reference, ISCED 1, 2) & 477 & 40.5 & .49 & 0 & 1 \\
$\quad$ Medium (ISCED 3, 4) & 477 & 27.0 & .45 & 0 & 1 \\
$\quad$ High (ISCED 5, 6) & 477 & 32.5 & .47 & 0 & 1 \\
Net household income (in $€, \log )$. & 456 & 7.06 & .66 & 3.69 & 9.43 \\
\hline
\end{tabular}

Table 3: Vignette dimensions

\begin{tabular}{lll}
\hline Dimension & Categories & $\#$ \\
\hline Heir's monthly gross income & $€ 1,750 / € 3,500 / € 10,000$ & 3 \\
Value of bequest & $€ 25,000 / € 100,000 / € 500,000 / € 1$ Mio / €10 Mio & 5 \\
Relation between testator and heir & Friend/uncle/grandfather/father & 4 \\
Type of bequest & Lump sum/owner-occupied property/family enterprise & 3 \\
Governmental debt & High/low & 2 \\
Heir's gender & Male/female & 2 \\
\hline
\end{tabular}


Table 4: Vignette sample

\begin{tabular}{crr}
\hline & $\begin{array}{r}\text { Frequency } \\
\text { absolute }\end{array}$ & $\begin{array}{r}\text { Frequency } \\
\text { in \% }\end{array}$ \\
\hline Heir's monthly gross income & 2874 & 100 \\
$€ 1,750$ & 897 & 31 \\
$€ 3,500$ & 966 & 34 \\
$€ 10,000$ & 1011 & 35 \\
Value of bequest & 2874 & 100 \\
$€ 25$, oo0 & 386 & 13 \\
$€ 100,000$ & 487 & 17 \\
$€ 500,000$ & 608 & 21 \\
$€ 1$ Mio & 683 & 24 \\
$€ 10$ Mio & 710 & 25 \\
Relation between testator and heir & 2874 & 100 \\
Friend & 575 & 20 \\
Uncle & 821 & 29 \\
Grandfather & 777 & 27 \\
Father & 701 & 24 \\
Type of bequest & 2874 & 100 \\
Lump sum & 999 & 35 \\
Owner-occupied property & 1177 & 41 \\
Family enterprise & 698 & 24 \\
Governmental debt & 2874 & 100 \\
High & 1425 & 50 \\
Low & 1449 & 50 \\
Heir's gender & 2874 & 100 \\
Male & 1437 & 50 \\
Female & 1437 & 50 \\
\hline
\end{tabular}


Table 5: Random intercept models (DV: proposed inheritance tax rate in percent, PITR)

\begin{tabular}{|c|c|c|}
\hline Models & $\begin{array}{c}(1) \\
\text { coef. (t-value) }\end{array}$ & $\begin{array}{c}(2) \\
\text { coef. (t-value) }\end{array}$ \\
\hline \multicolumn{3}{|l|}{ Fixed effects } \\
\hline \multicolumn{3}{|l|}{ Vignettes (Level 1) } \\
\hline Intercept & $16.45(25.22)^{* * *}$ & $16.45(25.49)^{* * * *}$ \\
\hline $\begin{array}{l}\text { Heir's monthly gross income (Re } \\
\quad € 3,500 \\
\quad € 10,000\end{array}$ & $\begin{array}{l}2.63(5.86)^{* * * *} \\
6.97(15.52)^{* * *}\end{array}$ & $\begin{array}{l}2.63(5.87)^{* * * *} \\
6.99(15.53)^{* * * *}\end{array}$ \\
\hline $\begin{array}{l}\text { Value of bequest (Ref.: } € 25,000) \\
\quad € 100,000 \\
€ 500,000 \\
€ 1 \mathrm{Mio} \\
€ 10 \mathrm{Mio}\end{array}$ & $\begin{array}{l}1.81(2.70)^{* *} \\
4.44(6.74)^{* * *} \\
6.10(9.44)^{* * *} \\
9.36(14.82)^{* * *}\end{array}$ & $\begin{array}{l}1.81(2.69)^{* * *} \\
4.44(6.73)^{* * * *} \\
6.10(9.43)^{* * * *} \\
9.37(14.83)^{* * *}\end{array}$ \\
\hline $\begin{array}{l}\text { Relation between testator and he } \\
\text { Uncle } \\
\text { Grandfather } \\
\text { Father }\end{array}$ & $\begin{array}{l}-1.67(-3.10)^{* *} \\
-2.29(-4.07)^{* * *} \\
-3.88(-6.99)^{* * *}\end{array}$ & $\begin{array}{l}-1.66(-3.07) * * \\
-2.27(-4.03) * * * \\
-3.85(-6.95)^{* * * *}\end{array}$ \\
\hline $\begin{array}{l}\text { Type of bequest (Ref.: lump sum } \\
\text { Owner-occupied property } \\
\text { Family enterprise }\end{array}$ & $\begin{array}{l}-2.09(-4.80)^{* * * *} \\
-4.07(-8.42)^{* * *}\end{array}$ & $\begin{array}{l}-2.08(-4.79)^{* * * *} \\
-4.07(-8.42)^{* * * *}\end{array}$ \\
\hline Governmental debt $(1=$ high $)$ & $1.63(4.57)^{* * *}$ & $1.61(4.53)^{* * * *}$ \\
\hline Heir's gender ( 1 = male $)$ & $-0.42(-1.26)$ & $-0.42(-1.26)$ \\
\hline \multicolumn{3}{|l|}{ Respondents (Level 2) } \\
\hline $\begin{array}{l}\text { Respondent expecting bequest } \\
>€ 25,000(1=\text { yes, } \mathrm{O}=\text { no })\end{array}$ & & $0.53(0.36)$ \\
\hline $\begin{array}{l}\text { Family-oriented } \\
\text { (index; } 1=\text { high, } \mathrm{o}=\text { low) }\end{array}$ & & $-10.38(-2.99)^{* *}$ \\
\hline \multicolumn{3}{|l|}{ Random effects } \\
\hline $\begin{array}{l}\text { Error variance Level } 1 \\
\text { Error variance Level } 2\end{array}$ & $\begin{array}{r}78.27 \\
190.66\end{array}$ & $\begin{array}{r}78.27 \\
186.45\end{array}$ \\
\hline $\mathrm{N}_{11 \_ \text {vignettes }}$ & 2874 & 2874 \\
\hline $\mathrm{N}_{12 \_ \text {respondents }}$ & 479 & 479 \\
\hline Deviance & 21986.11 & 21955.02 \\
\hline
\end{tabular}

Independent variables are grand-mean centered.

$* \mathrm{p}<.05, * * \mathrm{p}<.01, * \mathrm{p}<.001$

Control variables on respondents' level considered in model 2: gender, age, educational background and net household income (in $€, \log )$. 
Table 6: True tax liability for selected cases

\begin{tabular}{|c|c|c|c|}
\hline Vignette characteristics & $\begin{array}{l}\text { Effective tax rate } \\
\text { (tax payment/total } \\
\text { acquisition) }\end{array}$ & $\begin{array}{c}\text { Tax rate }(\$ 19 \text { ErbStG) } \\
\text { (tax payment/taxable } \\
\text { acquisition) }\end{array}$ & $\begin{array}{c}\text { Proposed inheritance tax } \\
\text { rate (PITR) }\end{array}$ \\
\hline $\begin{array}{l}\text { Lump-sum bequest of } € \\
25, \text { ooo from father } \\
\text { (grandfather) }\end{array}$ & $0.0 \%$ & $0.0 \%$ & $\begin{array}{c}12.6 \% \\
(14.2 \%)\end{array}$ \\
\hline $\begin{array}{l}\text { Lump-sum bequest of } € \\
100, \text { ooO from father } \\
\text { (grandfather) }\end{array}$ & $0.0 \%$ & $0.0 \%$ & $\begin{array}{c}14.4 \% \\
(16.0 \%)\end{array}$ \\
\hline $\begin{array}{l}\text { Lump-sum bequest of } € \\
500,000 \text { from father } \\
\text { (grandfather) }\end{array}$ & $2.2 \%$ & $11.0 \%$ & $\begin{array}{c}17.0 \% \\
(18.6 \%)\end{array}$ \\
\hline $\begin{array}{l}\text { Lump-sum bequest of } € \\
1 \text { mil from father } \\
\text { (grandfather) }\end{array}$ & $\begin{array}{c}9.0 \% \\
(15.2 \%)\end{array}$ & $\begin{array}{c}15.0 \% \\
(19.0 \%)\end{array}$ & $\begin{array}{c}18.7 \% \\
(20.3 \%)\end{array}$ \\
\hline $\begin{array}{l}\text { Lump-sum bequest of } € \\
10 \text { mil from father } \\
\text { (grandfather) }\end{array}$ & $\begin{array}{c}18.2 \% \\
(22.5 \%)\end{array}$ & $23.0 \%$ & $\begin{array}{c}22.0 \% \\
(23.6 \%)\end{array}$ \\
\hline $\begin{array}{l}\text { Lump-sum bequest of } € \\
25,000 \text { from uncle }\end{array}$ & $3.0 \%$ & $15.0 \%$ & $14.8 \%$ \\
\hline $\begin{array}{l}\text { Lump-sum bequest of } € \\
100,000 \text { from uncle }\end{array}$ & $16.0 \%$ & $20.0 \%$ & $16.6 \%$ \\
\hline $\begin{array}{l}\text { Lump-sum bequest of } € \\
500,000 \text { from uncle }\end{array}$ & $24.0 \%$ & $25.0 \%$ & $19.2 \%$ \\
\hline $\begin{array}{l}\text { Lump-sum bequest of } € \\
1 \text { mil from uncle }\end{array}$ & $29.4 \%$ & $30.0 \%$ & $20.9 \%$ \\
\hline $\begin{array}{l}\text { Lump-sum bequest of } € \\
10 \text { mil from uncle }\end{array}$ & $34.9 \%$ & $35.0 \%$ & $24.2 \%$ \\
\hline $\begin{array}{l}\text { Lump-sum bequest of } € \\
25,000 \text { from friend }\end{array}$ & $6.0 \%$ & $30.0 \%$ & $16.5 \%$ \\
\hline $\begin{array}{l}\text { Lump-sum bequest of } € \\
100,000 \text { from friend }\end{array}$ & $24.0 \%$ & $30.0 \%$ & $18.3 \%$ \\
\hline $\begin{array}{l}\text { Lump-sum bequest of } € \\
500,000 \text { from friend }\end{array}$ & $28.8 \%$ & $30.0 \%$ & $20.9 \%$ \\
\hline $\begin{array}{l}\text { Lump-sum bequest of } € \\
1 \mathrm{mil} \text { from friend }\end{array}$ & $29.4 \%$ & $30.0 \%$ & $22.6 \%$ \\
\hline $\begin{array}{l}\text { Lump-sum bequest of } € \\
10 \text { mil from friend }\end{array}$ & $49.9 \%$ & $50.0 \%$ & $25.8 \%$ \\
\hline
\end{tabular}

The effective tax rates are calculated using the standard allowances (father: $€$ 400,000; grandfather: $€$ 200,000; uncle: $€$ 20,000; friend: $€ 20,000)$ and tax rates in the respective tax classes. Additional pension allowances could be granted and would reduce the effective tax rates further 
Figure 1: Vignette example. The varying dimensions used in our design are embolded.

Mr. Miller inherits a family enterprise valued at $€ \mathbf{1 0 0 , 0 0 0}$ from his uncle. His monthly gross income is $€ \mathbf{1 , 7 5 0}$. The governmental debt of the country he lives in is currently high.

In your opinion, what is the percentage of the total value Mr. Miller should pay as inheritance tax?
$\mathrm{O}$
10
20
$30 \quad 40$
50
60
70
$80 \quad 90$
100
$\mathrm{O} O \mathrm{O} O$
$\mathrm{O} \mathrm{O}$
$\mathrm{O} \mathrm{O}$
O O O
$\mathrm{O} O \mathrm{O}$
$\begin{array}{lllll}\mathrm{O} & \mathrm{O} & \mathrm{O} & \mathrm{O}\end{array}$

Figure 2: Distribution of proposed inheritance tax rate, PITR (dependent variable)

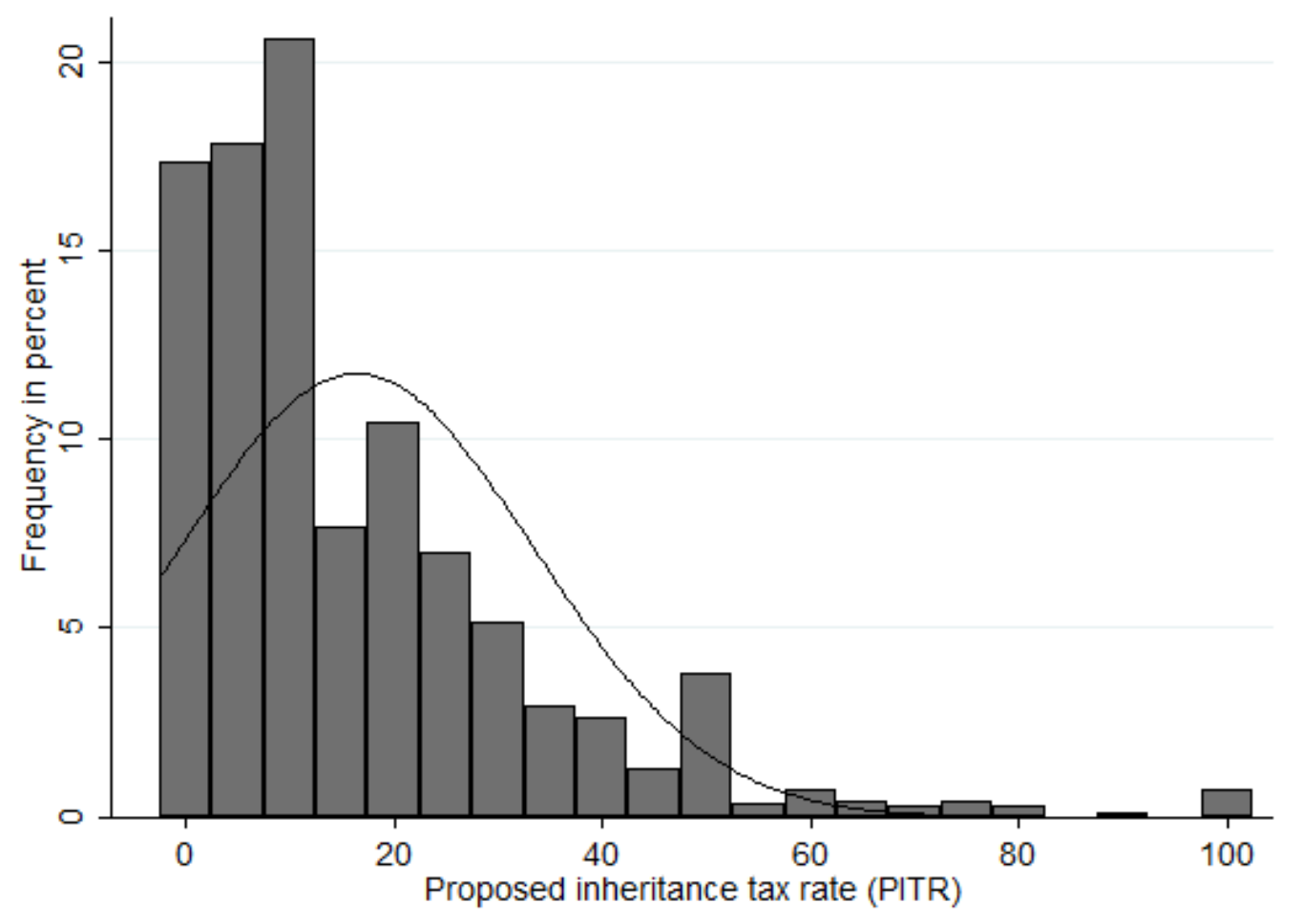

